\title{
Looking Inward or Outward? An Italian Experience of Prisoners' Involvement in Governance through Participatory Budgeting
}

\author{
Giovanni Allegretti* \\ Center for Social Studies, Coimbra University (Portugal) \\ PO box 3087, Coimbra, 3000-995, Portugal \\ Giorgio Pittella \\ BiPart Social enterprise, BASE Milano, via Bergognone 34, 20144 Milano, Italy
}

\begin{abstract}
The article refers to an experimental project called "Idee in fuga" ("Ideas on the run" or "Fleeing Ideas") which, for the first time, tried to adapt a model of actor-based participatory budgeting (PB) to a detention center environment, namely that of the "open-cell" prison of Milan - Bollate. The democratic practice - aimed to involve inmates in the governance of part of the decision making on their living environment's transformations is read in the light of the results of the filtering and voting phases, which happened between April 2019 and September 2020. The focus on the 58 proposals, and their transformation into 10 more polished projects, includes their organization in clusters, which are referred to ideas focussed (1) on the transformation of internal facilities, (2) on programmes intended to bridge with the "future life of inmates after the end-of-sentence", and (3) on transformations in the governance or regulations of the prisons. The visible difference between the types of proposals emerged in male and female wards (and more supported in each one) is discussed, in the light of the role played by the disparities of physical and organizational conditions between the different sections of the prisons.
\end{abstract}

Keywords: participatory budgeting; prisoners' engagement; Bollate; pilot project; governance

DOI: $10.7176 /$ RHSS/11-11-5

Publication date:June $30^{\text {th }} 2021$

\section{Introduction: within the narrative of democratic experiments in prisons}

Since the recommendation no. R (87) 3 of the Committee of Ministers of the Council of Europe on the European Prison Rules (1987), and especially after its revision operated by Rec 2006/2 (CoE, 2006), a multiplication of inprison practices have been implemented, directly involving inmates in the governance and evaluation of specific programmes which have been targeted towards them (especially on issues related to: education, employment and health).

However, insofar, few experiences have been imagining collective spaces where inmates, whilst incarcerated, could contribute to the governance, informing on perceived priorities (collectively assessed) and, especially, affecting the use of resources devoted to this aim (Brosens, 2019). Those which have been attempted, were often conceived in the form of councils and commissions, with a more or less permanent structure; so, they proposed architectures based on a representative principle, whose advocates and members were often appointed or suggested by self-selection on the basis of their active engagement in the in-ward community. As the comprehensive analysis proposed by Schmidt (2020) suggests, until now no deliberative experiments in prisons (using random sampling, in the form of mini-publics, deliberative polls or citizens panels/juries - see Sintomer, 2018; Fishkin, 2011, 2020) have been attempted, and in those which existed outside correctional institutions, the fact of being subjected to prison sentences played as an excluding factor (Gastil \& Wright, 2018: 313). Practices valuing the intensification of democratic "behind bars" (Inderbitzin et al., 2016) and in "unlikely places" (Dzur, 2019) exist, but they rarely tend to reach a large audience within the prison, to affect the traditional harsh chain of technobureaucratic decision-making that regulates correctional institutes, and reducing their external visibility, even if we refer to the attention dedicated to qualitative phenomena and prison-related innovations, by the carefully-written reports of institutions, as the European Prison Observatory, which monitor the actual detention conditions in 8 European Countries ${ }^{36}$ and is highly attentive to the diverse interpretive practices through which the call to threaten persons deprived of their liberty "with humanity and respect for human dignity" (a core CoE recommendation) is implemented (Heard, 2016). The persistent "invisibility" in gray and academic literature does not prevent a diverse range of practices to happen worldwide, centering their focus on "reimagining prisoners as active citizens through forms of participatory governance" (Schmidt, 2020) or through the use of cognitive/artistic methodologies such as the "Theatre of the Oppressed" by Augusto Boal (UNESCO BR, 2007), or even consolidating "bridges" between life inside and outside of prison around issues related to political rights and citizenship - as is the case of New York Participatory Budgeting's programmes, that involve ex-offenders in

\footnotetext{
${ }^{36}$ The countries include: France, United Kingdom, Greece, Italy, Latvia, Poland, Portugal, and Spain. See: http://www.prisonobservatory.org
} 
decision-making (PBPNYC-UJC, 2013: 27-28), or several reentry convicted criminal programmes (Fox, 2010; CESPI, 2005) which considers issues related to political activism and citizenship as a qualification dimension ${ }^{37}$.

This article aims to analyse some outcomes of a hybrid experience named "Idee in Fuga" (IIF - which can be translated as "Ideas on the run" or "Fleeing ideas" ${ }^{38}$ ), where the authors of this article were directly involved, playing different roles ${ }^{39}$ The pilot project was formally implemented in the Bollate experimental and "open-cell" prison (Mastrobuoni and Terlizzese, 2014, 2018), in the metropolitan area of Milan (Italy), between February 2019 and September 2020 and - at present - is still waiting for the delayed final results' implementation.

Promoted by a start-up called "BiPart" participatory practices, IIF carried out the first worldwide experiment of Participatory Budgeting or PB (Sintomer et al. 2012; Dias, 2018), conducted within a correctional institute, including all inmates as participants and proponents of ideas to be funded by a specific budget. Detainees could have a direct final say on this budget according to the results of a final voting session, which would be considered as binding or mandatory by the involved administration. The analysed practice can be considered as a "hybrid" for 3 reasons: (1) it was conceived as a "learning by doing" project, with an initial and stable "core-structure" inspired by PB, but open to ongoing changes which could increase its "maieutic function" in relation to participants, and its added value of discussing issues related to democracy and citizenship; (2) it involved a public institution (the prisional administration), but operated the binding-choices on an added extra-institutional budget, in order to ease approval procedures to allow the project to take off as a pilot for future improvements; (3) it limited its entitled participants to inmates (which is nothing new in PBs for schools), but tried to maintain a constant-open dialogue with external audiences via IIF's website, a board of supporting institutions and a civic crowdfunding platform through which BiPart did its fund-raising in order to collect the resources to implement prisoners' ideas.

In fact, a specificity of IIF is that it took shape as a totally grassroots project made up of a volunteering professional institution, with no initial funding; so, all organisational costs were covered by BiPart members and supporting entities, which gradually discovered the project and entered in its implementation phases. BiPart itself had no previous experience in prisonal environments, although some of its members have had, from previous collaborations with other grassroots or professional entities.

It is worth noting that IIF's development-timing exceeded all initial deadlines, due to slow negotiations (and several reassignments of tasks and roles) with the complex hierarchical chain-of-command ${ }^{41}$ in charge of the prisonal system in Italy, with the added pandemic outbreak complication, which paralysed its activities and all direct contact between inmates and voluntary workers. This evolving time frame required several adaptations, and does not allow to present here (as the authors wished) the project's final assessment and its first a posteriori impacts. Thus, this article focuses on final outputs of the co-decisional process which involved inmates, with the facilitation of BiPart volunteers, and will attempt to analyse them in the light of some adaptive changes which have been implemented during its almost 2-years' development, to overcome some barriers which have emerged in the research's course. Paragraph two highlights some peculiar characteristics of IIF, and the specificity of its context; paragraph three describes the planning, filtering and voting phases outcomes, in the light of the differences between men and women prison-sections; paragraph four proposes some final remarks related to this incomplete experience. A series of 44 interviews and 3 different surveys were distributed during IIF's different phases, and will be used to support the accurate interpretation of results; but they will not be the focus of this analysis $^{42}$.

\section{Motivations, architecture and timeline of an experimental project}

The IIF Project (whose name was chosen by the inmates, in the pre-project phase) was conceived earlier in 2016, as a pilot-experience of participatory governance in a "semi-isolated environment"; more specifically, a model of "actor-based" participatory budgeting (Cabannes, 2015), targeting incarcerated citizens, which could improve pre-existing prison-based practices, reaching a level of involvement of inmates in the governance of their living environment which had not been experienced before (NACRO, 2014). The idea, grounded on previous experiences of actor-based PB schools carried out by the Milan-based social enterprise BiPart, was carried on in

\footnotetext{
${ }^{37}$ See the French case: Drolez, B.; Maymil, V.; Palach, JM (2019).

${ }^{38} \mathrm{https}$ ://www.ideeinfuga.org

${ }^{39}$ G. Pittella had the first idea, negotiated with the prisional institute since 2017 (a member of BiPart); G. Allegretti initially joined the project as just a testimonial (https://www.ideeinfuga.org/ testimonial-giovanniallegretti), but later joined the team through a partnership with the Centre for Social Studies of the Coimbra University, to perform some monitoring/assessment functions on IIF.

${ }^{40} \mathrm{https}$ ///bipart.org

${ }^{41}$ I.e., during the development of IIF (February 2019- February 2021) three changes of Government occurred in Italy, with discontinuities at a high level in the Ministry of Justice (in charge of prisons).

${ }^{42}$ During the "filtering phase", a sample of 32 inmates (out of 58 who presented proposals) responded to satisfaction questionnaires distributed by the Centre for Social studies of Coimbra University. In the "voting phase" 177 surveys on satisfaction were answered (representing $34,7 \%$ of voters; $16,2 \%$ of inmates entitled to vote). Among women, the $\%$ of final survey respondents was much higher $(63.77 \%$ of voters vs $30.15 \%$ in male wards).
} 
a country which recently hosted several interesting innovative experiences of citizens participation applied to budget planning and management (Stortone \& Allegretti, 2018; Dias et al., 2019). It was imagined in a framework which sees "democratic professionalism" (Dzur, 2019) and voluntary sector as significant leverage for reshaping the culture of penal institutions (Abrams et al., 2016). Particularly, BiPart's professionals stated that rarely resources which enter prisons to support different socio/cultural projects, refer to activities conceived or co-designed with the participation of those which are imagined as beneficiaries. Therefore - as more than one of the interviewed prisoners underlined - "they are often inadequate in relation to our needs and priorities" and "disrespectful toward the people they declare they want to serve"43.

The Second Prison of Milan - Bollate appeared to be the natural choice, due to its innovative experimental status of "open-cell prison" that literature has analysed in order to prove its recidivism reducing capacity through lenient prison conditions (Mastrobuoni \& Terlizzese, 2018) and a series of vocation-based educational and rehabilitation programs, included those linked to: Teatro Galeotto (Garavaglia, 2014), equestrian rehabilitation (Villa \& Manca, 2016), cooperative work (Capato Sartore, 2013) body and movement pedagogies (Maccagno, 2015) and several action-research experiences (Di Franco, 2020) and participatory physical planning (Pedretti, 2012; Consalez, 2019). In particular, the opening of prison administration to directly involve inmates in planning everyday life in the correctional institute was made clear by (for over a decade) so-called Ward Commissions (or Committees). The latter are representative structures of advocacy made up of delegates or floor representatives elected by other inmates and coordinated by educators, ward-heads and volunteers to guarantee "the smooth running of life within the section, collecting reports that included problems or requests from all inmates and proposed ideas or initiatives" to the administration (Coop. Art 3, 2012). In Bollate, the creation of the Joint Commissions and their thematic structures - who meet monthly with the director and the Prison Police to discuss the problems of the penitentiary, allowing representatives of different wards to overcome the barriers between departments and section which are usually separated - had granted a mechanism of enlarged governance. The latter - despite the efforts - had had difficulties in overcoming the diffuse mistrust of many inmates which is naturally associated to "representativeness" in structures which appears as "inner circles" and spaces of privilege for some prisoners to get closer to the administrations and become "gatekeepers", thus reinforcing new internal hierarchies (Inderbitzin et al., 2016) within institutions that - "despite the inherently public nature of their task" are often "impervious to democratic innovation (...) nontransparent, hierarchical, and nonparticipatory" (Dzur, 2015), as many studies have proved since the seminal works of Scharf's (1975) and Marrero's (1977) to Dzur's analyses (2019, and Dzur \& Ercan, 2016).

IIF's goal in proposing a pilot-project of direct participation, within a detention institution, was that of check which diverse effects a path in which the incarcerated have some real budgetary power can generate, both for the detained population and on the administration. In particular, as far as in the prison subculture the inmates who somehow collaborate with the institutions are often defined as "infamous" or "quisling", the margins of the inner democratic life and the participatory dynamics tend to be reduced by this "social stigma". Consequently, a participatory budgeting experience, where all prisoners hold decision-making power on a specific envelope of resources, could be a "picklock" revealing to inmates the power that single individuals - through direct involvement and collaboration with others - could have during their sentences, especially in Milan-Bollate prison's case, which fully, attentively and effectively socially integrated its detainees, over the years, including their dimensions of active citizenship related to their interactive capacity with democratic rules (Schmidt, 2020).

A quick overview of the project timeline shows the long and difficult negotiation which needed to be approved. In the winter of 2017, it was first submitted to the Head of the Treatment Area, who, subsequently, submitted it to the scrutiny of the Joint Culture Commission (mainly made up of prisoners), as it was envisioned as a "cultural activity". From 2017 to 2019, BiPart carried out the co-design work of the PB project with the same Commission and administration of the Prison House (represented by the Director and the Chief Commissioner) which - together - constituted the "coordination council" responsible for composing the rules and architecture of the phases' processes. The preliminary decision of separating two tracks of action (for both female wards and male wards) was suggested by male prisoners, assuming different needs and an evident imbalance between male and female inmates (the women being 1/6 of men - so around 200 out of about 1200 inmates) would generate incommensurable differences in their budget proposals and would under-represent women's needs. Taking into account that: (1) the female area is detached from the central body of the prison (occupied by men's wards but also by the working areas, the infirmary and the treatment area) and; (2) the ratio of the total of on parole women or women on work permit residing in Ward 5 (called Article 21 or "ex OP", coming from a legal framework) is higher, and this group is often absent from the prison when cultural activities are carried out which could increase the underrepresentation of women in the process. Accordingly, the initial budget of 20,000 $€$ of crowdfunded resources (due to implement the first priority most voted in the male and in

\footnotetext{
${ }^{43}$ These two statements were part of 16 interviews collected by CES researcher(s) during the project; some of which (included inmates upon their consent) have been filmed by 808 Film Production, as a reminiscence of the project. One of the proposals presented in IIF (which got 23 votes) was polemically entitled "Professional up to date relevant skilled work, not classic obsolete activities".
} 
the female PBs), was split into two equal parts, as no opposition to such a decision has emerged - opposite of what was expected ${ }^{44}$. The project - unlike the initial idea - established that this pot of resources, needed to assure at least a minimum concrete result to "encourage" inmates' participation, were going to be collected among donors and granted since the beginning, while the online civic crowdfunding platform would add further resources to eventually implement priorities other than the first which established by male and female prisoners. This decision was taken at the beginning of 2019, when the public launch of IIF (Nappi, 2019) - despite the construction of a large network of supporting institutions and social organisations ${ }^{45}$ - highlighted the risk that the crowdfunding pace could be slow in the phases in which the projects' proposals were still under construction by the inmates, and that a reduced visibility "outside the prison" could impact the commitment of the "insiders" in the absence of a guaranteed pot of resources.

Internally, since the start of 2019, the process included: 9 information meetings held in each of the 6 wards of the main prison block, in the female session and the infirmary; 9 co-planning meetings facilitated by BiPart, in order to help inmates to elaborate proposals to be presented and 3 final inter-ward meetings where inmates from different wards could interact with other inmates in respect to the proposed ideas. This phase of "brainstorming of ideas" lasted 2 months and was followed by the so-called "support phase", intended as a space open to all inmates to vote for their "favourite" among the first round of proposals in order to: rank them, filter their number and then proceed to merge the similar ones or compose complementary ideas ${ }^{46}$. The ranking of proposals happened in April 2019 and consisted of 10 proposals (the first 5 of male and female sections) were selected to access the next phase of the process. A more "deliberative" process (called the "planning phase") followed this filtering exercise, and it lasted from May 2019 to December 2019, being prolonged until early February 2020 as requested by detainees. In this phase, the proponent inmates (accompanied by other interested parties, included proponents of similar or complementary ideas left behind in the filtering phase) met with detention house management and experts to detail their proposals and transform them into polished finished projects.

Unfortunately, the final voting session imagined for February 2020 (one year after the official start of IIF) was cancelled due to the restrictive measures determined by the pandemic outbreak of COVID-19, and could only be held for 5 days at the end of September $2020^{47}$, when BiPart volunteers were allowed to re-enter in the prison premises. Although Bollate has been in the vanguard of Italian prisons during the first pandemic wave, adopting innovative measures to maintain the maximum possible connections with the outside world (Ripamonti, $2020)^{48}$, the project - much of which centred is in the face-to-face dialogue between the inmates and the volunteers, which had to come from outside the prison - was forcibly suspended, also due to general rules aimed to reduce the co-presence of many people in the same venue. Possibly, if the numbers of participants in the two voting rounds (the "support" filtering vote on initial proposals, and the final vote on definitive projects) differ ${ }^{49}$ as shown in Table. 1 - this is partially due to the long interruption of seven months, which somehow cooleddown the linear development of the project during 2020. Anyway, the final vote on September 2020 sanctioned the projects that could immediately be realised with available resources.

\section{Insert Table 1}

\section{Outcomes as mirrors of the daily constraints}

The deliberative phase of IIF resulted in 58 proposals from inmates and prisoners (47 coming from male wards and 11 from female ones), whose emergence took a longer length of time and more support of the project voluntary workers than originally planned. As the detainees tried to explain themselves, this unexpected slowness could be a reflex of the fact that they were "not used to elaborating on ideas" as "projects in prison are mostly delivered as ready-to-wear packages conceived somewhere else" and "a change in attitude requires time and energy"; but also could derive from "a different pace of time in the prison that makes it difficult to imagine the rhythm which is required by those who come from the outside" and from "some embarrassment in having to put on paper needs and requests about what we talk about daily, but not expecting someone who will really listen to us" ${ }^{\prime \prime}$.

According to the guiding idea around which detainees have shaped the title of IIF (that "ideas can make fly

\footnotetext{
${ }^{44}$ Both BiPart and the Prison administration expected the emergence of claims to divide the resources in parts proportional to the number of inmates of male and female sections.

${ }^{45}$ The 8 Testimonials and the 13 supporting institutions can be found here: https://www.ideeinfuga.org/proposal/carcere-di-bollate- 9

46 The voting method chosen provided a list of all proposals, among which each detainee could mark one or more (with no limitations) which (s)he considered meaningful for continuing the process.

${ }^{47}$ Strong restrictions marked the participation of prisoners in the vote. In fact, it was only allowed in the morning, so that many prisoners who were working outside Bollate could not vote, and voting in the infirmary (where persons with COVID-19 or suspected of having it were held) was forbidden.

${ }^{48}$ See also the issue $\mathrm{n} .1$ of Balthazar (July 2020): Testimonianza dal carcere di Bollate (p. 206-210).

${ }^{49}$ The filtering phase, managed almost entirely by the inmates with the support of BiPart facilitators, saw 670 inmates voting (out of 1278 entitled - a turnout of $52.4 \%$ ). In the women wards had a turnout of $80.2 \%$, while in the male wards it was around $48.6 \%$.

${ }^{50}$ These statements come from 4 different interviews realised to inmates by CES and 808 Collective.
} 
outside the prison walls"51), we initially clustered all proposals into three categories, depending on whether they aimed to: (1) revamp facilities and services inside the prison in order to improve the "present life of detainees" (which we will call "in ward proposals"); (2) propose new (or enhance the quality of existing) programmes and training courses that bridge with a vision of the "tomorrow outside the prison" (which we will call "out of ward proposals"); (3) to visualise transformations in prison governance or regulations, and eventually in the broader legal framework.

As evident from tables $\mathrm{XX}$ and $\mathrm{XX}$, a visible difference emerged between the type of proposals coming from male and female wards, and were more strongly supported in each sub-area of the prison: i.e., 34 out of 47 proposals provided and ranked by men, referred to as "out of ward", were conceived to prepare detainees' "tomorrow life" (and they got 1333 preferences, so $82.7 \%$ of the 1612 casted votes) ${ }^{52}$; conversely, 8 out of 11 proposals emerged from female wards supported internal reforms of the prison's spaces and services (resulting in $75.7 \%$ of the 557 votes cast), as the establishment of a self-managed laundry service (which is missing in the department but present in the male section), the renewal of showers, a horse riding course (already present in the institute, in the men's part), an ice cream bar and the modernisation of the kitchens. In the long planning phase, where some proposals were discarded due to the lack of their feasibility (such as the horse riding course) and others merged (generating the idea of a cold food bar which reinforced the previous idea of an "ice cream bar") this trend consolidated, and an interesting debate grew around the "modernisation of the kitchens" and the "renovation of the showers", which many considered a "due commitment" to be fulfilled through ordinary administration and did not need to "waste" extraordinary resources as those of IIF. During the debate among female inmates, several recurrent thoughts appealed, mainly to detainees' personal responsibility, against the damage of common spaces (i.e. removing metal pieces for personal use in their cells), and it was explicitly said that the list of proposals could be used as a platform for collective future claims, to give the prison administration a clear view of the most consensual transformations required by inmates. Here, undoubtedly, the collective dynamics aimed to consensus building prevailed, gradually converging onto the need of prioritised investments that could - at the same time - respond to needs felt in the daily inner life (and asymmetric conditions in relation to male wards), without putting aside the possibility of learning skills which could help in the "outside world" dimension.

Conversely, in the male wards, the excessive ambition of some proposals prioritised in the filtering phase in relation to available budgets obliged to erase them (as in the case of the milk transformation into dairy) or resize them (i.e. the "pet hostel", which became a dog training course). If none of the erased proposals were replaced with those immediately following in the ranking, it was because of the reduced feasibility was verified late, and too close to the final voting event ${ }^{53}$. In general, the debate among male inmates reflected greater attention to an "out of ward" and "end-of-sentence" dimension.

The list of the five most voted proposals for the different areas confirms the above-mentioned different approaches between male and female wards: in fact, in the latter, none of the 5 most voted proposals were concerned with only imagined activities from an out of ward perspective, and 3 of them were merely referred to as transformations of inner spaces, while in the male wards only one proposal was explicitly aiming to infrastructural improvements, the remaining 4 all linked to an out of ward perspective. Graphs 1 and 2 highlight such trends, which were confirmed by both votes (one on initial proposals and then a final vote). It is worth emphasising that the only proposal clusterable in the "policies" category came from Ward 5, which houses the so-called "Art. 21", the semi-free detainees who can work outside: thus, inmates who "live" in the detention house for a limited time, who proved less interested in both the "indoor" present, as well as in a vision which can bridge them to a better future dimensions, which has been partially guaranteed to them.

\section{Insert Graphs 1 and 2}

So, the outcomes of the different "selection phases" through inmates' voting (which constitutes the empowering specificity of a participatory budgeting method) and the co-planning meetings between detainees and IIF volunteers seem to confirm the hypothesis it soon emerged during the co-design phase with the Culture Commission: that the asymmetric presence of structures and services could improve quality of life in male and female wards could heavily weigh on the results of the process, and that is why it was important to separate the two tracks of action (and resources) dedicated to men and women, from the beginning. Although the hypothesis had been formulated by a representative (and reduced) sample of prisoners, it was confirmed by many through the process of ideation and voting. As confirmed by detainees (both male and female) in the interviews, these

\footnotetext{
${ }^{51}$ Many of the 58 projects also were given names referred to as ideas of proposed activities as a way to "escape" from the prison's daily routine (Sport Escape; Escaping with fashion; Let's cut the rope! etc.).

${ }^{52}$ In the male wards, the most supported proposals were two job centres to match external job demands and internal offers; a dairy that could sell products outside and inside the institution; a pet boarding and the restyling of the computer room.

${ }^{53}$ Actually, due to the delays related to the COVID-19 outbreak, it could have been possible to replace them during the spring or summer of 2020 , but the inmates decided they did not want to do it in the absence of IIF volunteers, who could not enter the prison up until September 2020
} 
asymmetries - attributed to a "lack of attention to gender imbalances of the prison centre administration, more than to a structural problem in the prison creation" 54 - have ended up attributing "a different meaning to the IIF process itself in the male and female wards", and "this possibly explains the differences in the commitment, participation and interaction with the volunteers on the part of the women, who saw the project as an anchor and a rare opportunity to present an articulated platform of claims- even if in the form of proposals- to the administration" 55 . Under this perspective, the model of participatory budgeting chosen for IIF expanded its potential uses, has served its purpose (especially in the female wards) in remarking on the "ontology" of existing problems, not sacrificing them to a mere "solution oriented" perspective (Heron \& Reason, 1997): therefore incorporating a vision typical of the participatory inquiry paradigm, a form of research which already had interesting applications and theoretical framings in detention environments (Brosens et al, 2015; Walsh et al, 2014; Ward \& Bailey, 2013; Martin, 2009; Dupont, 2008; Fine \& Torre, 2006; Fine, 2003), and even in criminological research (Dupont, 2008). In the case, even if a non-systematic form, of IIF's creators imagined the PB pilot-project as a practical opportunity to start answering a diverse set of questions related to different potentials of participatory practices, through a methodology of "learning by doing", whose connotations relate to a maieutical Freirian perspective, where education represents "both a struggle for meaning and a struggle over power relations" (Giroux, 1985: xiii).

In this perspective, it is interesting to extract, from the surveys to participants which accompanied the three main phases of IIF, some data related to the extent to which the process was felt by participants as a satisfactory occasion to dialogue with the prison administration ${ }^{56}$. Clustering voters of the final voting sessions in groups ${ }^{57}$, male inmates appeared to be much more satisfied $(42.9 \%$ vs $28.9 \%)$ than female inmates, who showed higher rates of dissatisfaction ( $34.2 \%$ for women vs $24.3 \%$ for men). In part, this could be a consequence of a phenomena, which data highlights and was confirmed as a general rule for life in prison, by several interviewees: i.e. women had - in general - a little degree of interaction with the administration (57.9\% of respondents) compared to men $(44.5 \%)$, although data referred to similar significant interaction $(23.7 \%$ for women and $25.7 \%$ for men).

\section{Insert Graph 3 and 4, or leave at the end}

These perceptions somehow confirm that a link between the persistent asymmetries among male and female wards generates a vicious circle, that affect the relation with the administration, and also their capacity of taking advantage of a project with shared governance, that puts inmates at the centre, to modify the interrelations with the prison administration. It is worth underlining that, in a survey done with $55 \%$ of the active inmates who presented proposals in the PB process during the "appreciation and support phase", 81.3\% agreed that if participant would work properly, the project has the potential to "improve the relationships between prisoners and the prison administration", while $30 \%$ had envisioned it as "useful to reinforce the visibility of inmates" previous requests which were made to the prison administration", since the beginning. It can be also stressed that when surveying the less committed detainees who merely voted in the "support phase" - without presenting proposals - $36.4 \%$ of respondents agreed that IIF "is - somehow - a way of doing politics".

As a detainee put it in an interview, the participatory budgeting experiment took the shape of "a gradual exercise of maturation for those who live here, as it mixed moments of strong realism and some utopian horizons" - thanks to its multiple and diverse horizontal interactions among detainees, its collaborative spaces of co-design with the pre-existent Commissions representative of inmates and the administration, and the permanent dialogue with the external BiPart volunteers. In this perspective - as another inmate noted - "there have always been mixed feelings about doing something not only for the sake of the quality of life in prison, or merely for the future life outside". This is especially true "taking into account that we are many, and we have different genders, human and criminal stories and we serve sentences of different lengths and for different crimes (...) but we are called to participate in a common process, where voting is just one step toward something larger, something which aims to share consensus about solutions and innovative ideas to be - maybe - implemented, and with scarce resources" 58 .

Under this perspective, it could be interesting - in the light of the final outputs of the voting phase $\mathrm{s}^{59}$ - to recluster the 58 initial proposals through a larger series of families, which have been considered since the beginning of hybrid typologies where both in ward and out of ward elements coexisted, or policy perspectives

\footnotetext{
${ }^{54}$ Interview with a female detainee.

${ }^{55}$ Interview with a male detainee

${ }^{56}$ The final questionnaire was completed by 177 inmates $(40 \%$ of female voters, $13 \%$ of men). Q17 (How would you score the level of satisfaction in terms of the communication and relations with the prison administration?) and Q19 (Indicate the degree of interaction you had with the administration within IIF) which were answered by 145 inmates (34.7\% of voters: 107 men, 38 women).

${ }^{57}$ Answers originally provided a scale of values 0-10. Answers to Q17 grading satisfaction from 0 to 4 were classified in the "unsatisfactory" macro-area; answers with value 5 in the "indifferent" area and from 6 to 10 in the "satisfactory"; answers to Q19 grading personal interaction 0-4 were considered as "little interaction"; score 5 was considered "indifferent" and answers 6-10 of "significative interaction".

${ }^{58}$ Interview with a male detainee from Ward 5.

${ }^{59}$ See: https://www.ideeinfuga.org/vote
} 
mixed with transformations were applied to spaces and services inside the prison walls. In fact, the co-planning phase for elaborating and detailing the projects to be submitted to the final vote increasing the visibility of the original proposals" "mixed nature". Tables 2 and 3 propose this reclassification exercise in details for all the original ideas, while tables 4 and 5 offer a summarising overview of the two voting phases in male and female wards, according to the new five interpretative clusters.

\section{Insert Table 2 and 3 and 4 and 5 , or leave them at the end}

This is clear if one analyses the most voted projects of the female wards (the "bar in the female visitation area", with 51 votes, and the "laundry service", which collected 25 votes), both imagined in connection with a new cooperative, which could manage them generating management skills and paid employment, including a component of professional training that could be spent outside. The recategorisation can be applied also to the winners of the male wards' PB: the ex-aequo (with 185 votes each) to two job-centre projects, and the 142 votes cast for "Let's get to know our animal friends better", which was conceived (since the beginning, when it was a "pet hostel") as a project of social responsibility, which could benefit society (being part of the fight against pets' abandonment), but also inmates - offering a sort of "pet therapy" and skills for future jobs. In this case, it confirms the prevalence of projects "oriented to a life beyond punishment", but remarks the importance of mixing in ward and out of ward perspectives, while the projects classified as third (the renewal of ICT classroom for men, and of the showers for women) underline that IIF could serve also as an occasion to "report" internal needs and stress asymmetries of quality and adequacy existing in different parts of the prisons or between spaces devoted to different activities. Somehow, this richer form of re-clustering proposals and projects seems more aligned with the discussion among detainees and volunteers during the development of the different PB phases.

\section{Final remarks}

This article describes, for the first time, some aspects of a pilot-project which was named "Idee in Fuga" (IIF "Fleeing ideas" or "Ideas on the run"), on proposal of the involved detainees ofBollate prison in Milan (Italy), an experimental "open-cell" structure which since 2000 has been hosting a large series of innovative practices and testing new approaches to: detention and to cultural, educational and employment activities, which could guide the restructuring of the prison system in a country whose 189 correctional centres are overcrowded at $119 \%$ ratio $^{60}$. Striving to extend and intensify the forms of participatory involvement of inmates tested since a decade in Bollate through the Prisoners Commissions and Joint Committees, IIF seeks to adapt to a total institution the model of actor-based participatory budgeting (PB). The latter, already used in schools and universities within the large number of Italian PB experiences, tries to show that also in prisons it would be possible to reach the "devolving" stage - where prisoners are the decision makers of (some) choices regarding their lives in the institution (NACRO, 2014: 7) - of the simplified version of Arnstein's ladder of engagement and participation, which have been used in the last decade to classify different experiences of "democracy behind the bars" (Brosens, 2019, 2015; Taylor, 2014).

Coordinated by BiPart social enterprise, with its outstanding track-record in PB experiences, the IIF Project shows - as in other cases initiated by democratic professionalism - "the aspiration to create power-sharing arrangements and collaborative thinking skills in places that are usually characterised as hierarchical and nonparticipatory (Dzur \& Ercan, 2016: 94), contributing to transform the way a correctional institution functions and finding solutions to collective problems of inmates, by giving them the opportunity of "learning by doing" while directly contributing to planning of some investments which can transform their living environment and quality of life.

This article describes the experimental project and its phases aiming to progressively refine projects and programmes to benefit the detainees, while intensifying the relationship between them and the prison administration; and it focuses on confronting two different lines of action which have emerged in male and female wards. Outputs highlight a sort of path-dependency, which - in connection with structural asymmetries between male and female subsections of Bollate - affect the results of the proposal and the ranking of priorities by inmates. From the analysis, some interviews that help to refine its interpretation and the description of the slow pace that delayed the project's end and dilated some phases in relation to original planning, it appears that IIF remained heavily dependent on the volunteers' presence and the administration did still not take ownership of it. Even the crowdfunding to multiply its concrete results beyond the mere implementation of the first priority indicated by the final vote is still slow and limp.

Therefore, at the moment, the process appears rich, but the results don't allow for unambiguous conclusions; and is difficult to say if the completion of the "implementation phase" (beyond the cycle of co-decision) will take place as expected, thus affecting the degree of satisfaction of detainees who took part in it. This is the main reason why the authors decided not to use them in this article a lot of the rich materials which have emerged

${ }^{60}$ When the project started, there were 60,254 detainees in Italian prisons, being that the maximum formal capacity should be 50,480 (Source: Ministry of Justice, July 2019). 
from the three surveys that accompanied the monitoring of IIF's major phases, as it seems that participants' feelings have been empowered (or not) will largely depend on the extent to which the final concretisation of the project will happen as originally imagined or will appear weaker and fallacious.

IIF has shaped as a space which will increase the respect for detainees' self-organisational and selfdetermination capacity, and has given active democratic engagement to disenfranchised citizens. But it is proving - as demonstrated by Schmidt's recent studies (2020) - how difficult is, in the peculiar environment represented by correctional institutions, to increase their democratic intensity and reach higher emancipatory effects. This challenge represents the main issue in discussing if IIF is due to remain as as (albeit innovative) participatory experiment, or it can aspire to replicability improve conditions of major independence (from both prison administration and volunteering organisations) at the same Bollate, or in other numerous institutions which in the last year declared their interest to emulate the experience.

In the authors' view, only if such transformative practices were the focus of democratic theorists even if they apparently "fall outside of the established notions of democracy" (Dzur \& Ercan, 2016: 94), they can have more chances to expand and increase their potential of fostering a deeper democratic change.

\section{Acknowledgments}

The authors wish to thank the staff, the detainees (in particular Biagio Aversano) and the volunteers who participated in this project, and the organisations which helped to fund it. Special thanks go to Stefano Stortone, Giulia Barbieri, Marta Quagliuolo, Alfredo Campos, Francisco Venes and Lev Shilov for the precious support.

\section{References}

Abrams, L.S., Hughes, E., Meek, R., Inderbitzin M. et al. (2016, eds). The Voluntary Sector in Prisons. Encouraging Personal and Institutional Change. Palgrave Macmillan

Brosens, D. (2015). Participation in prison programmes. Profile of (non-)participants, encouraging and discouraging factors. PhD thesis, Vrije Universiteit Brussel, Belgium.

Brosens, D. (2019). Prisoners' participation and involvement in prison life: Examining the possibilities and boundaries. European Journal of Criminology, 16(4), 466-485.

Brosens, D., De Donder, L.,\& Dury S (2015). Building a research partnership in a prison context. From collaboration to co-construction. Sociological Research Online 20(3).

Cabannes, Y. (2015). The impact of participatory budgeting on basic services: municipal practices and evidence from the field. Environment and Urbanization, 27(1), 257-284.

Capato Sartore, M. (2013). "The e.s.t.i.a. cooperative: a bridge between prison and "the outside". Economia della Cultura, Società, issue 4, 519-526.

CESPI (2005), Rimpatrio forzato e poi? Analisi dell'impatto delle espulsioni di differenti categorie di migranti: un confronto tra Albania, Marocco e Nigeria Working. Rapporto finale di ricerca del progetto ALNIMA Working Papers CESPI, 13/2005

CoE (2006) European Prison Rules. Strasbourg: Council of Europe Publishing: https://rm.coe.int/europeanprison-rules-978-92-871-5982-3/16806ab9ae.

Consalez, L. (2019), A symbolic project at Bollate. Abitare, 26/03/2019. https://www.abitare.it/en/architecture/projects/2019/03/26/bollate-prison-little-house-visits-inmateschildren

Coop. Art. 3 (2012), Tutto Bollate 2012. Guide. Articolo 3/Fondazione Cariplo

Di Franco, A. (2020). Tracce di Libertà: due esperienze di ricerca - azione nel carcere di Bollate. Il Giornale dell'architettura, May 2020, 1-2

Dias, N. (2018, org.), Hope for Democracy. 30 Years of Participatory Budgeting Worldwide. Oficina/Epopeia

Dias, N., Enríquez, S., \& Júlio, S. (2019, org.). The Participatory Budgeting World Atlas 2019. Epopeia/Oficina.

Drolez, B., Maymil, V., \& Palach, JM (2019), Rapport de Mission relative à la réforme de l'aide à la réinsertion familiale et sociale des anciens migrants dans leur pays d'origine (ARFS). République Française Inspection Générale des Affaires Sociales.

Dupont, I. (2008). Beyond Doing No Harm: A Call for Participatory Action Research with Marginalized Populations in Criminological Research. Crit Crim 16, 197 (2008)

Dzur, A. \& Ercan, S. (2016), Participatory Democracy in Unlikely Places: What Democratic Theorists Can Learn from Democratic Professionals. Journal of Democratic Theory, 3 (2), 94-113

Dzur, A. (2015). Public Restorative Justice: The Participatory Democratic Dimensions of Institutional Reform. Raisons politiques, 3(3), 51-71.

Dzur, A.W. (2018). Rebuilding Public Institutions Together: Professionals and Citizens in a Participatory Democracy. Cornell University Press.

Dzur, A.W. (2019). Democracy Inside: Participatory Innovation in Unlikely Places. Oxford University Press.

Fine, M. (2003). Participatory action research: From within and beyond bars, in Camic, P. , Rhodes, J.E. \& 
Yardley, L. (eds.). Qualitative research in psychology: Expanding perspectives in methodology and design. American Psychological Association, 173-198

Fine, M., \& Torre, M. A. (2006). Intimate details: Participatory action research in prison. Action Research, 4(3), 253-269

Fishkin, J. (2011). When the People Speak: Deliberative Democracy and Public Consultation. Oxford University Press

Fishkin, J. (2020). Democracy When the People Are Thinking : Revitalizing Our Politics Through Public Deliberation. Oxford University Press.

Fox, KJ. (2010). Second Chances: A Comparison of Civic Engagement in Offender Reentry Programs. CJR 35 (2010), 335-353

Garavaglia, V (2014), Teatri di confine: il postdrammatico al carcere di Bollate. Mimesis Edizioni

Gastil J., Wright, E.O. (2018). Legislature by Lot: Envisioning Sortition within a Bicameral System. Politics \& Society, 46(3), 303-330

Giroux, H. (1985). "Introduction." In P. Freire, The Politics of Education: Culture, Power, and Liberation, Bergin and Garvey.

Heard, C. (2016). Alternatives to imprisonment in Europe: A handbook of good practice European Prison Observatory. Antigone Edizioni

Heron, J., \& Reason, P. (1997). A Participatory Inquiry Paradigm. Qualitative Inquiry, 3(3), 274-294.

Inderbitzin, M., Cain J., \& Walraven, T. (2016). Learning and practicing citizenship and democracy behind bars. In: Abrams et al. (eds) The Voluntary Sector in Prisons. Encouraging Personal and Institutional Change. Palgrave Studies, 55-83

Maccagno, P. (2015), Running walls: the performance of the limit in prison. Scottish Journal of Performance, 2 (2), $32-58$

Marietti, S. (2019), Prison conditions in Italy. 2nd edition. European Prison Observatory. Antigone Edizioni

Marrero, D. (1977) Spatial Dimensions of Democratic Prison Reform: Human Space and Political Participation in Prison. The Prison Journal, 57(2), 31-42.

Martin, R.E. (2009). The development of participatory health research among incarcerated women in a Canadian prison. Intl. Journal of Prisoner Health, 5(2), 95-107.

Mastrobuoni G.; Terlizzese, D. (2018), Leave the door Open? Prison Conditions and Recidivism. Carlo Albeerto Notebook, n. 580

Mastrobuoni, G.; Terlizzese, D. (2014), Rehabilitation and Recidivism: Evidence from an Open Prison. S.E. http://www.antoniocasella.eu/nume/Mastrobuoni_Terlizzese_bollate_oct14.pdf

NACRO (2014). Prisoner Participation in Open and Training Prisons. A Toolkit for Prison Staff. Nacro.

Nappi, R. (2019), Carcere Bollate, per la prima volta al mondo il bilancio partecipativo è fatto dai detenuti: "Così contano davvero". Il Fatto quotidiano, 01/03/2019

PBPNYC-UJC (2013), A People's Budget: A Research and Evaluation Report on Participatory Budgeting in New York City - Year 2. Community Development Project at the Urban Justice Center/PBNYC Research Team

Pedretti, E. (2012). Un luogo da dove ricominciare. Esperienze di progettazione partecipata al carcere di Bollate. MA Thesis in Architecture, Politecnico di Milano

Ripamonti, S. (2020), Bollate, carcere modello. Anche nell'emergenza "Covid-19". The Huffingtonpost, $22 / 03 / 2020$

Scharf, P. (1975). Democracy and prison reform: A theory of democratic participation in prison. The Prison Journal, 55, 21-33.

Schmidt, B. (2020). Democratising Democracy: Reimagining Prisoners as Active Citizens Through Participatory Governance (Doctoral thesis).

Sintomer, Y. (2018). From deliberative to radical democracy? Sortition and politics in the twenty-first century. Politics \& Society, 46(3), 337-357.

Sintomer, Y., Herzberg, C., Röcke, A., \& Allegretti, G. (2012). Transnational Models of Citizen Participation: The Case of Participatory Budgeting. Journal of Public Deliberation, 8 (2), Art. 9

Stortone, S., \& Allegretti, G. (2018). Participatory Budgeting in Italy. Towards a Renaissance?. In Dias, N. (org.), Hope for Democracy. 30 Years of Participatory Budgeting Worldwide. Oficina/Epopeia, 289-309

Taylor, C. (2014). Brain Cells. Listening to Prisoner Learners. Prisoners' Education Trust.

UNESCO BR (2007). Educating for freedom: trajectory, debates and proposals of a project for education in Brazilian prisons. Proceedings of National Seminar "Consolidation and Guidelines of Education in Prisonal System". UNESCO

Villa, C., \& Manca, F. (2016). La riabilitazione equestre nella devianza sociale. In Cairo, MT (org.). Interventi Assistiti con gli Animali Problemi e prospettive di riflessione e di lavoro. EDUCatt.

Voluntary Sector in Prisons. Encouraging Personal and Institutional Change. New York: 
Walsh, E., Forsyth, K., Senior J. et al. (2014). Undertaking action research in prison: Developing the older prisoner health and social care assessment and plan. Action Research 12(2), 136-150.

Ward, J., \& Bailey, D. (2013). A participatory action research methodology in the management of self-harm in prison. Journal of Mental Health, 22 (4), 306-316.

\section{TABLES and GRAPHS}

Table 1 - Inmates' participation in the "support" and "voting" phases

\begin{tabular}{|c|c|c|c|c|c|c|}
\hline & \multicolumn{2}{|c|}{ Males } & \multicolumn{2}{|c|}{ Females } & \multicolumn{2}{|c|}{ Total } \\
\hline & Support phase & Voting phase & Support phase & Voting phase & Support phase & Voting phase \\
\hline Inmates & & & & & & \\
\hline $\begin{array}{l}\text { Entitled to } \\
\text { vote }\end{array}$ & 1125 & 982 & 153 & 111 & 1278 & 1093 \\
\hline Voters & $547(48,6 \%$ & $441(44,9 \%)$ & $123(80,3 \%)$ & $69(62,1 \%)$ & $670(52,4 \%)$ & $510(46,6 \%)$ \\
\hline
\end{tabular}

Graph 1 - Percentage of the 58 proposals (presented in male and female wards) belonging to the three main clusters.

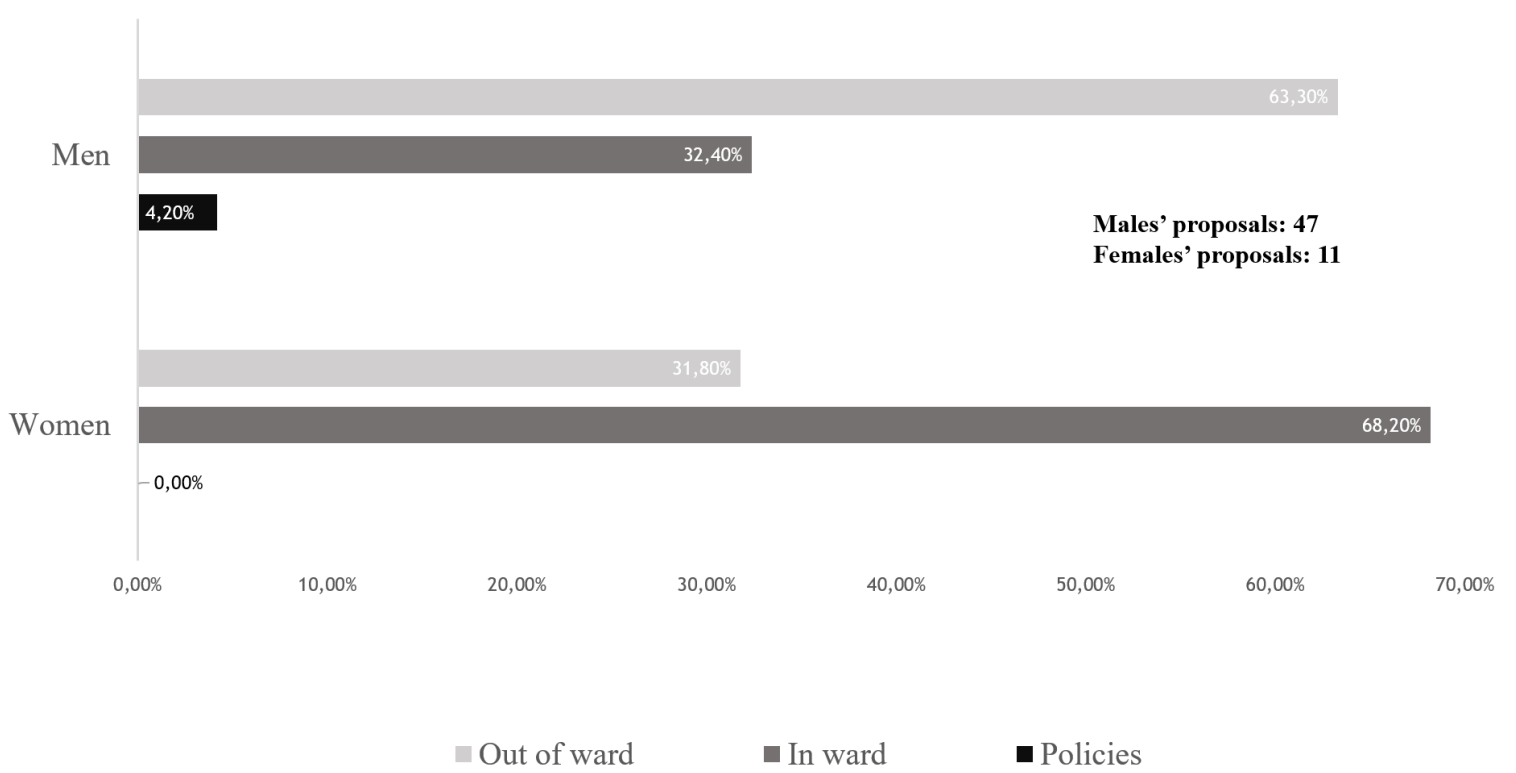

Graph 2 - Different distribution of votes in male and female wards during the "appreciation and support phase", according to the three main typologies used to cluster the 58 proposals.

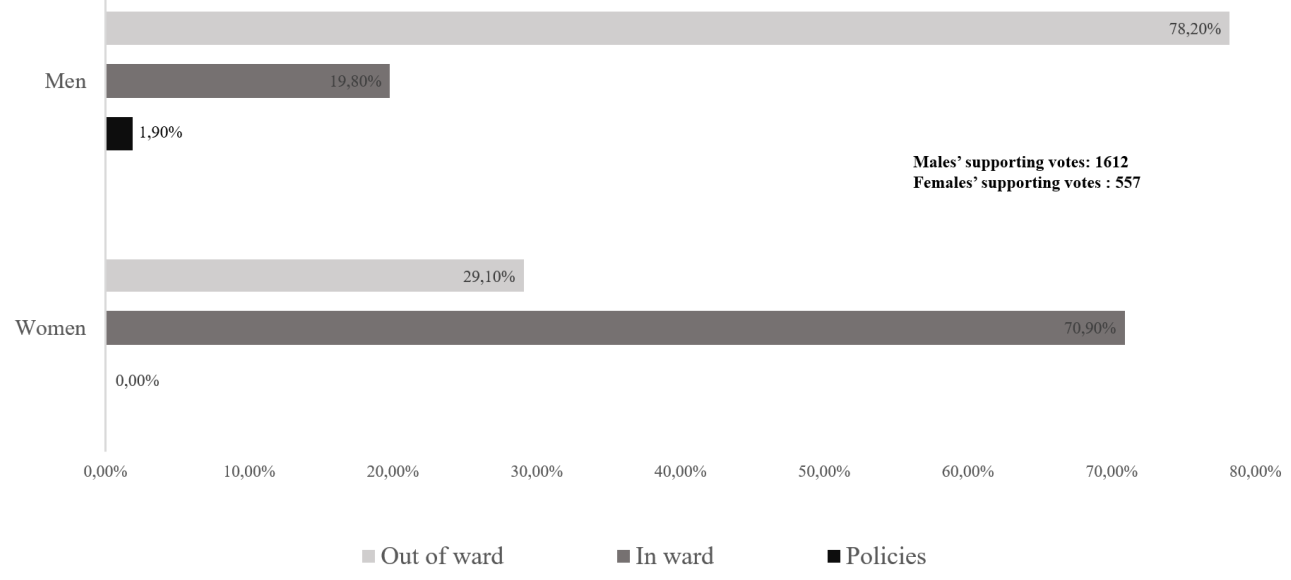


Table 2 - Re-clustered proposals in male wards (with scores obtained in the "support phase")

\begin{tabular}{|c|c|c|c|c|c|c|}
\hline Name of proposal & $\begin{array}{c}\text { Votes } \\
\text { obtained }\end{array}$ & $\begin{array}{l}\text { Outward } \\
\text { proposals }\end{array}$ & $\begin{array}{c}\text { Inward } \\
\text { proposals }\end{array}$ & $\begin{array}{c}\text { Policy } \\
\text { proposals }\end{array}$ & $\begin{array}{l}\text { Hybrid } \\
\text { proposal } \\
\text { (Inward/ } \\
\text { outward) }\end{array}$ & $\begin{array}{c}\text { Hybrid } \\
\text { proposal } \\
\text { (Inward/ } \\
\text { policy) }\end{array}$ \\
\hline Job center 1 & 200 & 200 & 0 & 0 & 0 & 0 \\
\hline Job center 2 & 167 & 167 & 0 & 0 & 0 & 0 \\
\hline Pet recovery 1 & 93 & 93 & 0 & 0 & 0 & 0 \\
\hline Informatic classroom restyling & 83 & 0 & 83 & 0 & 0 & 0 \\
\hline Production of dairy products & 83 & 83 & 0 & 0 & 0 & 0 \\
\hline Welding courses & 68 & 68 & 0 & 0 & 0 & 0 \\
\hline Pet recovery 2 & 0 & 0 & 0 & 0 & 60 & 0 \\
\hline Packaging company & 57 & 57 & 0 & 0 & 0 & 0 \\
\hline $\begin{array}{l}\text { Rotisserie specialised in Sicilian } \\
\text { "arancine" }\end{array}$ & 57 & 57 & 0 & 0 & 0 & 0 \\
\hline Bollate multiservice & 54 & 54 & 0 & 0 & 0 & 0 \\
\hline Jail art & 54 & 54 & 0 & 0 & 0 & 0 \\
\hline $\begin{array}{l}\text { C.p.c.c }-\quad \text { (collective prisonal } \\
\text { composting center) }\end{array}$ & 48 & 0 & 0 & 0 & 48 & 0 \\
\hline $\begin{array}{l}\text { Electrician, plumber, bricklayer, } \\
\text { blacksmith courses }\end{array}$ & 42 & 42 & 0 & 0 & 0 & 0 \\
\hline Work in progress & 38 & 38 & 0 & 0 & 0 & 0 \\
\hline Calling from jail & 32 & 0 & 0 & 0 & 0 & 32 \\
\hline Publishing house and literary prize & 29 & 29 & 0 & 0 & 0 & 0 \\
\hline $\begin{array}{l}\text { Consortium "il panettiere" (the } \\
\text { baker) Bollate s.n.c }\end{array}$ & 29 & 29 & 0 & 0 & 0 & 0 \\
\hline Family visits always in the garden & 27 & 0 & 27 & 0 & 0 & 0 \\
\hline Green visitations & 24 & 0 & 24 & 0 & 0 & 0 \\
\hline $\begin{array}{l}\text { Professional up to date relevant } \\
\text { skilled work, not classic obsolete } \\
\text { activities }\end{array}$ & 23 & 23 & 0 & 0 & 0 & 0 \\
\hline Music studio and a record label & 22 & 22 & 0 & 0 & 0 & 0 \\
\hline Adopt a grandfather & 21 & 21 & 0 & 0 & 0 & 0 \\
\hline Sportswear inside & 19 & 0 & 19 & 0 & 0 & 0 \\
\hline $\begin{array}{l}\text { Cut the rope - hairdressers and } \\
\text { barbers at your service }\end{array}$ & 19 & 0 & 0 & 19 & 0 & 0 \\
\hline $\begin{array}{l}\text { Looking for purpose }=\text { let's learn } \\
\text { skills able to work }\end{array}$ & 18 & 18 & 0 & 0 & 0 & 0 \\
\hline Recycling wood & 17 & 17 & 0 & 0 & 0 & 0 \\
\hline $\begin{array}{l}\text { Saving the Italian doc hens from } \\
\text { extinction }\end{array}$ & 17 & 17 & 0 & 0 & 0 & 0 \\
\hline Snail farming & 16 & 16 & 0 & 0 & 0 & 0 \\
\hline At least, affection for everyone & 16 & 0 & 0 & 0 & 0 & 16 \\
\hline $\begin{array}{l}\text { Brand New (warm fresh air): } \\
\text { space for a theater, and a cinema } \\
\text { available } 365 \text { days a year ... } 24 \\
\text { hours a day!!! }\end{array}$ & 16 & 0 & 16 & 0 & 0 & 0 \\
\hline Closed fists - the sequel & 15 & 0 & 15 & 0 & 0 & 0 \\
\hline A theatrical production & 14 & 0 & 14 & 0 & 0 & 0 \\
\hline Let's donate blood! & 14 & 14 & 0 & 0 & 0 & 0 \\
\hline Sport as an escape & 13 & 0 & 13 & 0 & 0 & 0 \\
\hline Seeds of freedom & 13 & 13 & 0 & 0 & 0 & 0 \\
\hline Online shop & 11 & 11 & 0 & 0 & 0 & 0 \\
\hline Free crafts & 10 & 10 & 0 & 0 & 0 & 0 \\
\hline Recycling place 2.0 & 10 & 0 & 0 & 0 & 10 & 0 \\
\hline Lottery (winning numbers) & 9 & 9 & 0 & 0 & 0 & 0 \\
\hline
\end{tabular}


Table 2 - Re-clustered proposals in male wards (with scores obtained in the "support phase")

\begin{tabular}{|l|l|l|l|l|l|l|}
\hline \multicolumn{1}{|c|}{ Name of proposal } & $\begin{array}{c}\text { Votes } \\
\text { obtained }\end{array}$ & $\begin{array}{c}\text { Outward } \\
\text { proposals }\end{array}$ & $\begin{array}{c}\text { Inward } \\
\text { proposals }\end{array}$ & $\begin{array}{c}\text { Hybrid } \\
\text { Policy } \\
\text { proposals }\end{array}$ & $\begin{array}{c}\text { Hybrid } \\
\text { proposal } \\
\text { proposal } \\
\text { Inward/ } \\
\text { outward) }\end{array}$ & $\begin{array}{c}\text { (Inward/ } \\
\text { policy) }\end{array}$ \\
\hline $\begin{array}{l}\text { Environmentally } \\
\text { generator with magnetic energy }\end{array}$ & 8 & 0 & 0 & 0 & 8 & 0 \\
\hline Un-divided & 8 & 0 & 0 & 0 & 8 & 0 \\
\hline $\begin{array}{l}\text { Cerebro: the Bollate that was not } \\
\text { there }\end{array}$ & 7 & 7 & 0 & 0 & 0 & 0 \\
\hline The Third Pole & 7 & 0 & 0 & 7 & 0 & 0 \\
\hline All fresh & 7 & 0 & 7 & 0 & 0 & 0 \\
\hline Free to think & 6 & 0 & 6 & 0 & 0 & 0 \\
\hline $\begin{array}{l}\text { Everything that flows through a } \\
\text { thread }\end{array}$ & 6 & 0 & 6 & 0 & 0 & 0 \\
\hline Ex forma & 5 & 5 & 0 & 0 & 0 & 0 \\
\hline & & $\mathbf{1 1 7 4}$ & $\mathbf{2 3 0}$ & $\mathbf{7}$ & $\mathbf{1 5 3}$ & $\mathbf{4 8}$ \\
\hline
\end{tabular}

Table 3 - Re-clustered proposals in the female wards (with scores obtained in the "support phase")

\begin{tabular}{|c|c|c|c|c|c|c|}
\hline Proposal & $\begin{array}{c}\text { Votes } \\
\text { obtained }\end{array}$ & $\begin{array}{l}\text { Outward } \\
\text { proposals }\end{array}$ & $\begin{array}{c}\text { Inward } \\
\text { proposals }\end{array}$ & $\begin{array}{c}\text { Policy } \\
\text { proposals }\end{array}$ & $\begin{array}{c}\text { Hybrid proposal } \\
\text { (Inward/ } \\
\text { outward) }\end{array}$ & $\begin{array}{c}\text { Hybrid } \\
\text { proposal } \\
\text { (Inward/ } \\
\text { policy) }\end{array}$ \\
\hline Laundry service & 86 & 0 & 0 & 0 & 86 & 0 \\
\hline $\begin{array}{l}\text { Let's renew the } \\
\text { showers }\end{array}$ & 73 & 0 & 73 & 0 & 0 & 0 \\
\hline Ice-cream service & 64 & 0 & 0 & 0 & 64 & 0 \\
\hline $\begin{array}{l}\text { More equipped and } \\
\text { functional kitchens }\end{array}$ & 56 & 0 & 56 & 0 & 0 & 0 \\
\hline $\begin{array}{l}\text { Empowering horse } \\
\text { driving course }\end{array}$ & 51 & 0 & 45 & 0 & 0 & 0 \\
\hline Bar and snack bar & 46 & 0 & 0 & 0 & 46 & 0 \\
\hline $\begin{array}{l}\text { Maintenance } \\
\text { green spaces }\end{array}$ & 45 & 0 & 45 & 0 & 0 & 0 \\
\hline Gym & 37 & 0 & 37 & 0 & 0 & 0 \\
\hline $\begin{array}{lr}\text { Tailoring } & \text { course I } \\
\text { (escaping } & \text { with } \\
\text { fashion) } & \\
\end{array}$ & 35 & 35 & 0 & 0 & 0 & 0 \\
\hline $\begin{array}{l}\text { Planting a } \\
\text { vegetable garden }\end{array}$ & 35 & 0 & 35 & 0 & 0 & 0 \\
\hline $\begin{array}{l}\text { Tailoring course II } \\
\text { (cutting and } \\
\text { sewing) }\end{array}$ & 29 & 29 & 0 & 0 & 0 & 0 \\
\hline Total & & 64 & 297 & $\mathbf{0}$ & 196 & $\mathbf{0}$ \\
\hline
\end{tabular}


Graph 3 - Distribution of answers to Q17 (in male and female wards): How would you score the level of satisfaction in terms of the communication and relations with the prison administration?

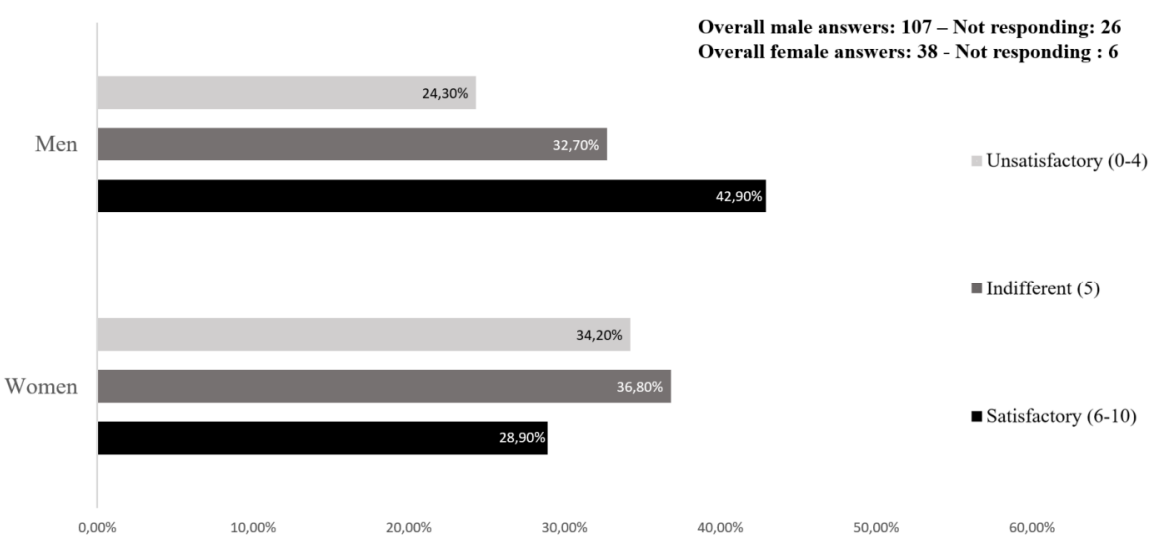

Graph 4 - Distribution of answers to Q19 (in male and female wards): Indicate the degree of interaction you had with the administration within IIF

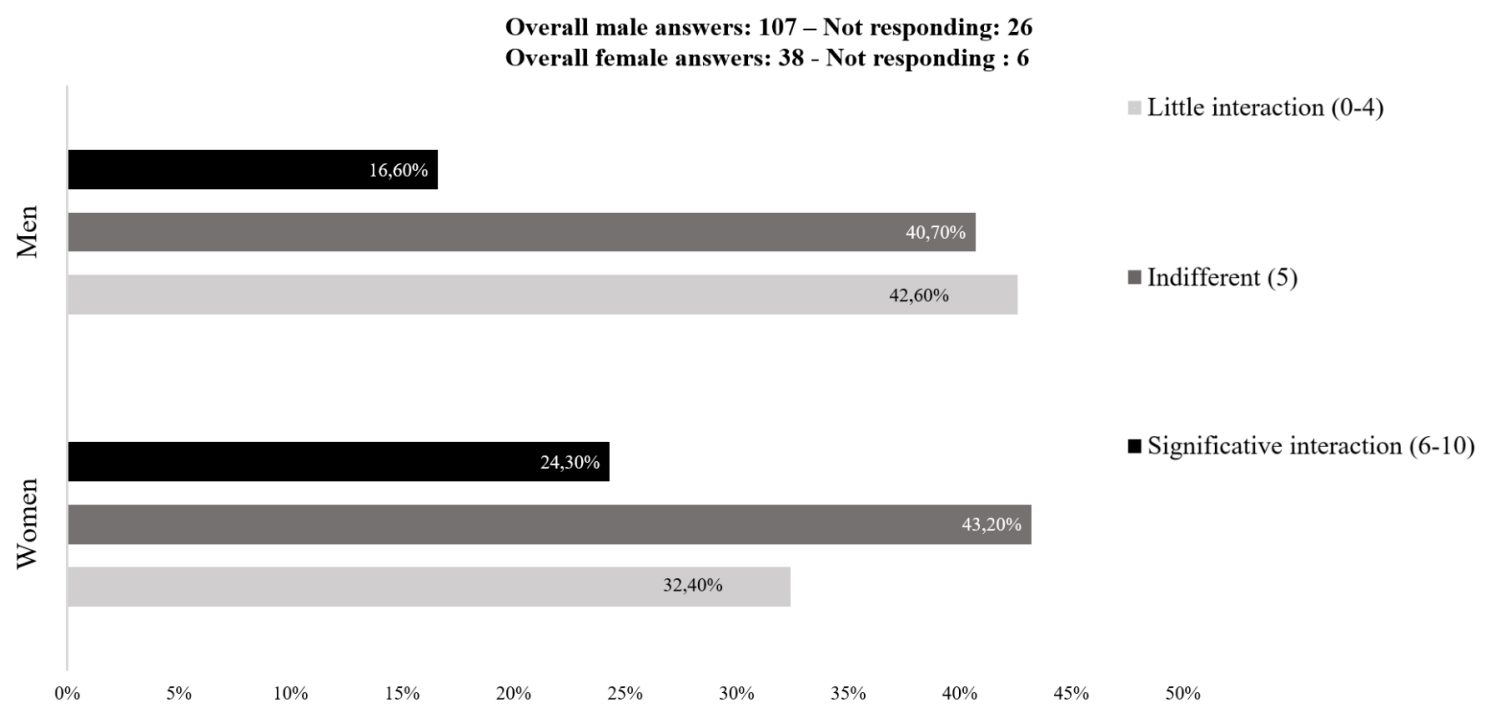

Table 4 - Re-clustered proposals: $n^{0}$ and votes received in male and female wards during the ranking of the "appreciation and support phase"

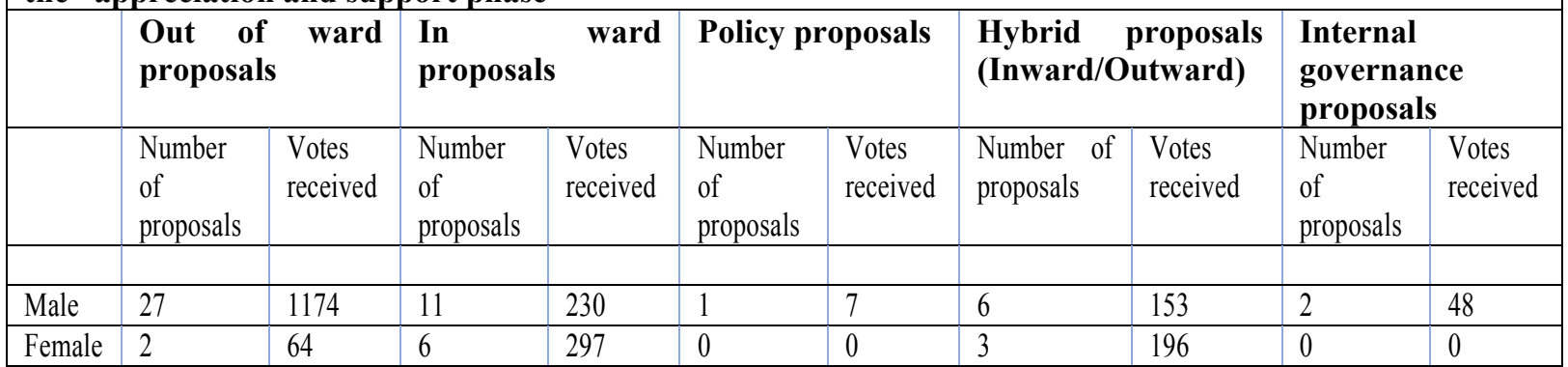


Table 5 - Re-clustered projects: $\mathrm{n}^{0}$ and votes received in male and female wards during the "voting phase"

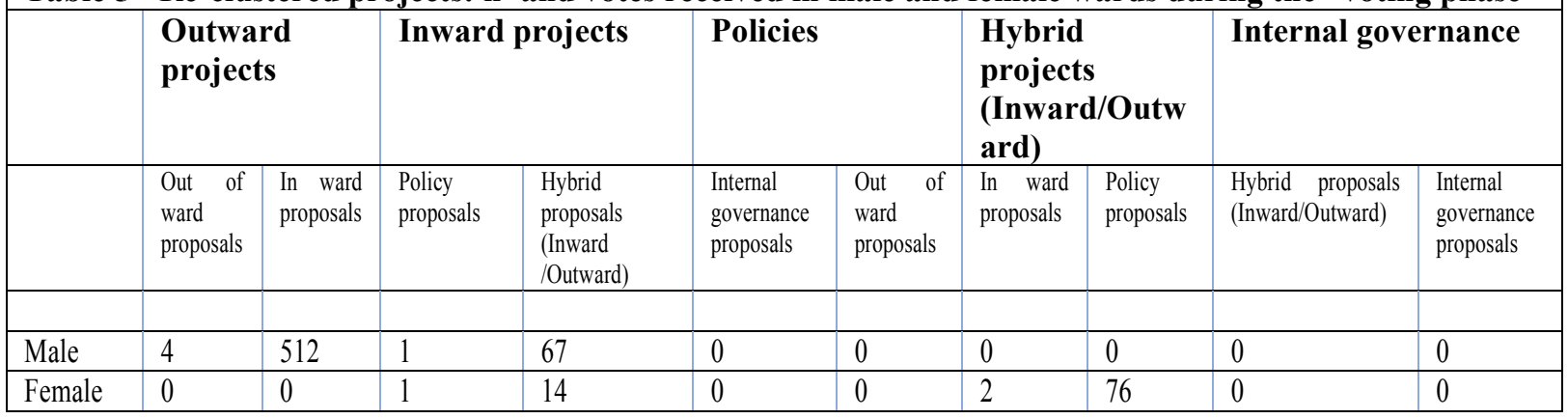

